\title{
COMBINING ABILITY AMONG SIX COMMON BEAN CULTIVARS ADAPTED TO THE NORTH WEST REGION OF PARANÁ STATE, BRAZIL
}

\author{
MARCO ANTONIO APARECIDO BARELLI ${ }^{(2)}$; MARIA CELESTE \\ GONÇALVES-VIDIGAL ${ }^{(2)}$; ANTONIO TEIXEIRA DO AMARAL JÚNIOR ${ }^{(3)}$; \\ PEDRO SOARES VIDIGAL FILHO ${ }^{(2)}$; CARLOS ALBERTO SCAPIM ${ }^{(2)}$
}

\begin{abstract}
Eight morpho-agronomic traits have been measured in six common bean (Phaseolus vulgaris L.) cultivars and their 15 hybrids aiming to estimate parents potential per se and heterotic effects of hybrid combinations (Gardner and Ebehart's method, 1966). Enough variability has bees detected among the parents for most of the studied characters. Excepting first pod insertion height the results have shown a great deal of complementation for the scored traits. Hybrids LPSPI 93-17 x FT Nobre and LPSPI 93-19 $x$ FT Nobre have revealed the highest chances of selecting for earlier plant emergence and flowering cycle; on the other hand, 'LPSPI 93-17', 'Ápore', 'Rudá' and 'Campeão-1' have presented high potentials per se, as well as in hybrid combinations, for grain yielding increases.
\end{abstract}

Key words: Phaseolus vulgaris, diallel analysis, heterosis.

\section{RESUMO \\ HABILIDADE COMBINATÓRIA ENTRE SEIS CULTIVARES DE FEIJOEIRO ADAPTADOS AO NOROESTE PARANAENSE}

Parametrizações heteróticas, via método de Gardner e Ebehart (1966), de oito características agronômicas das variedades de feijoeiro comum (Phaseolus vulgaris L.) LPSPI 93-17, LPSPI 93-19, FT Nobre, Aporé, Rudá e Campeão-1 e seus 15 híbridos dialélicos foram estimadas para avaliar o potencial per se dos genitores e os efeitos heteróticos nas combinações híbridas. Suficiente variabilidade genética ocorreu entre os genitores avaliados para a maioria das características, o que é favorável à aplicação do melhoramento genético. Excetuando-se altura de inserção da primeira vagem, os resultados evidenciaram complementação gênica satisfatória para as características avaliadas. Maiores potenciais para redução no período de emergência e de florescimento foram expressos nas combinações 'LPSPI 93-17' x ‘FT Nobre' e 'LPSPI 93-19' x ‘FT Nobre'. Em relação a aumentos na produção de grãos, 'LPSPI 93-17' ,'Aporé', 'Rudá' e 'Campeão-1' são as de maior potencial per se ou para compor programas de híbridos.

Palavras-chave: Phaseolus vulgaris, análise dialélica, heterose.

$\left({ }^{1}\right)$ Received in July $23^{\text {rd }}, 1999$ and approved in May $9^{\text {th }}, 2000$.

${ }^{2}$ Departamento de Agronomia, Av. Colombo 5.790, Bloco 32, Universidade Estadual de Maringá (UEM), $87020-900$ Maringá (PR). E-mail: mbarelli@terra.com.br

$\left({ }^{3}\right)$ Laboratório de Melhoramento Genético Vegetal, Centro de Ciências e Tecnologias Agropecuárias, Universidade Estadual do Norte Fluminense, 28015-620 Campos dos Goytacazes (RJ). 


\section{INTRODUCTION}

The common bean plant is part, along with rice, of the basic diet of the Brazilian people, especially the poorest population (VIEIRA, 1988). The national productivity, however, is low (about $600 \mathrm{~kg}^{-h^{-1}}{ }^{\text {) }}$ and there have been significant imports of the product to meet the internal market needs (DEMARCHI, 1995).

The Northwest of Paraná State has a contribution to the state production of less than $2 \%$ of the total (DEMARCHI, 1997). This underlines the need to develop cultivars with greater yield capacity with adaptation to the area.

Greater bean yield could be obtained by hybridizing superior cultivars. The diallel cross procedure is a viable alternative for this, as it allows wide recombination of the genes, with greater possibility of obtaining superior genotypes (VENCOVSKY, 1970; SouZA JúNIOR, 1981; PAINI, 1994).

Gardner and Ebehart's method (1966) is a good option for the analysis of the diallel data because it provides detailed information on heterosis, through analytical parameterization, and on the parental potential per se (VENCOVSKY, 1970; SINGH AND SINGH, 1984; CRUZ AND REgAZZI, 1994).

This study involved six common bean cultivars adapted to the Northwest Region of Paraná crossed in a diallel plan aiming to assess the mean varietal and specific heterosis among parents and hybrids of eight agronomic traits. Gardner and Ebehart's method (1966) was used as a first step in developing promising cultivars for the region.

\section{MATERIAL AND METHODS}

Six common bean cultivars, described in Table 1, were crossed to obtain a complete diallel without reciprocals.

The populations (six parents and $15 \mathrm{~F}_{1}$ 's) in a total of 21 treatments were evaluated from September to November 1997 in a greenhouse of the Department of Agronomy of the Universidade Estadual de Maringá, State of Paraná, Brazil. A randomized complete block

Table 1. Morphological/agronomic traits of the bean plant cultivars used in the experiment

\begin{tabular}{|c|c|c|c|c|c|}
\hline Cultivars & Growth habit & Seed size & Commercial group & Cycle days & Disease resistance \\
\hline LPSPI 93-17 $7^{(1)}$ & $\begin{array}{l}\text { Indeterminate } \\
\text { prostated } \\
\text { (III) }\end{array}$ & Average & Carioca & $94-95$ & $\begin{array}{l}\text { R - Oidium } \\
\text { MR - Rust } \\
\text { MR - Anthracnose } \\
\text { S - Bacteriosis } \\
\text { S - Angular spot }\end{array}$ \\
\hline LPSPI 93-19 & $\begin{array}{l}\text { Indeterminate } \\
\text { prostated } \\
\text { (III) }\end{array}$ & Average & Colors & $90-91$ & $\begin{array}{l}\text { MR - Bacteriosis } \\
\text { MR - Oidium } \\
\text { S - Anthracnose } \\
\text { S - Angular spot }\end{array}$ \\
\hline FT-Nobre & $\begin{array}{l}\text { Indeterminate erect } \\
\text { (II) }\end{array}$ & Average & Colors & $90-92$ & $\begin{array}{l}\text { MR - Anthracnose } \\
\text { MR - Angular spot } \\
\text { MR - Rust } \\
\text { S - Bacteriosis }\end{array}$ \\
\hline Aporé(2) & $\begin{array}{l}\text { Indeterminate } \\
\text { prostated } \\
\text { (III) }\end{array}$ & Average & Carioca & $92-93$ & $\begin{array}{l}\mathrm{R} \text { - Mosaico-comum } \\
\mathrm{R} \text { - Rust } \\
\text { MR - Anthracnose } \\
\text { MR - Angular spot } \\
\text { MR - Bacteriosis }\end{array}$ \\
\hline Rudá & $\begin{array}{l}\text { Indeterminate } \\
\text { prostated } \\
\text { (II and III) }\end{array}$ & Average & Carioca & 90 & $\begin{array}{l}\mathrm{R} \text { - Rust } \\
\mathrm{R} \text { - Mosaico-comum } \\
\text { MR - Bacteriosis } \\
\mathrm{S} \text { - Anthracnose } \\
\mathrm{S} \text { - Angular spot }\end{array}$ \\
\hline Campeão-1 & $\begin{array}{l}\text { Indeterminate } \\
\text { prostated } \\
\text { (III) }\end{array}$ & Average & Carioca & $92-93$ & $\begin{array}{l}\mathrm{R} \text { - Anthracnose } \\
\mathrm{R} \text { - Rust } \\
\text { MR - Angular spot } \\
\text { MR - Bacteriosis }\end{array}$ \\
\hline
\end{tabular}

${ }^{(1)}$ Orange halo. ${ }^{(2)}$ Yellow halo, tolerance to drought. $\mathrm{R}=$ resistance. $\mathrm{MR}=$ moderate resistance. $\mathrm{S}=$ susceptible. 
design with ten replications was used and the experimental unit was made up of one pot with two plants.

The following traits were assessed:

a) mean number of days to emergence (MNDE): obtained from the ratio between the number of days from sowing and the emergence of the cotyledon at soil level in all plants in each treatment.

b) number of days to flowering (NDF): the number of days from sowing to the complete opening of the first flower on each plant in each treatment.

c) mean height of first pod insertion (MHFPI): obtained from the ratio between the distances from the soil to the insertion of the first pod and the respective number of plants in each treatment (expressed in centimeters, obtained with a tape measure).

d) mean longitudinal length of the pods (MLLP): obtained by measuring the pod length from one longitudinal extremity to the other, in a random sample of ten pods from each treatment (expressed in centimeters, obtained with a tape measure).

e) mean final plant height (MFPH): obtained from the ratio between the measurements from the soil level to the highest point of the plants and the respective number of plants in each treatment (expressed in centimeters, obtained with a tape measure).

f) mean seed number per pod (MSNP): obtained from the ratio between the total number of seeds and the total number of pods produced per plant in each treatment.

g) mean seed weight (MSW): obtained by weighing a 50 grain sample from each treatment (expressed in grams).

h) grain yield (GY): obtained from the ratio between the total weight of the grains of the treatments and the respective number of plants (expressed in $\mathrm{g} /$ plant).

The statistic analysis was calculated by using Gardner and Ebehart's method II (1966).

\section{RESULTS AND DISCUSSION}

\subsection{Analysis of variance for cultivars and heterosis}

The analysis of variance displaying the partition of the treatments in the genetic effects due to cultivars (parents) and heterosis (Table 2). This then is partitioned in mean heterosis, varietal and specific mean heterosis. The mean squares associated with the treatment effects and cultivars were highly significant $(\mathrm{P}<0.01)$ for all the assessed traits. Heterosis was significant for all traits at the levels considered, except for MHFPI.

The heterotic estimates showed that: a) only the NDF and MHFPI traits had no significant mean heterosis; b) significant or highly significant varietal heterosis was found for MNDE $(\mathrm{P}<0.01)$, NDF $(\mathrm{P}<0.01), \mathrm{MFPH}(\mathrm{P}<0.05)$ and NMSC $(\mathrm{P}<0.05)$; and C) there was significant or highly significant specific heterosis for the MNDE $(\mathrm{P}<0.01)$, NDF $(\mathrm{P}<0.05)$, $\operatorname{MLLP}(\mathrm{P}<0.01)$ and MFPH $(\mathrm{P}<0.05)$.

The significant mean square values for mean heterosis for the majority of the traits indicate that there was sufficient genetic divergence among the parents assessed, resulting in a favorable situation for breeding.

In spite of no significance for mean heterosis for the NDF trait there was sufficient gene dispersion to express significance for the effects of varietal and specific heterosis, showing that, at least partially, the

Table 2. Analysis of variance of eight agronomic traits assessed in diallel crosses among six common bean cultivars, according to Gardner and Ebehart's method (1966)

\begin{tabular}{|c|c|c|c|c|c|c|c|c|c|}
\hline \multirow[t]{2}{*}{ SV } & \multirow[t]{2}{*}{ DF } & \multicolumn{8}{|c|}{ Mean squares ${ }^{(1)}$} \\
\hline & & MNDE & NDF & MHFPI & MLLP & MFPH & MSNP & MSW & GY \\
\hline Treatment & 20 & $5.6489^{* *}$ & $13.3062^{* *}$ & $33.3108^{* *}$ & $2.3331^{* *}$ & $2668.2321^{* *}$ & $0.8271^{* *}$ & $9.7318^{* *}$ & $71.2287^{* *}$ \\
\hline Cultivars & 5 & $13.7832^{* *}$ & $41.0361^{* *}$ & $103.9280^{* *}$ & $7.0977^{* *}$ & $3446.0161^{* *}$ & $1.2881^{* *}$ & $31.6651^{* *}$ & $227.2811^{* *}$ \\
\hline Heterosis & 15 & $2.9375^{* *}$ & $4.0629^{* *}$ & $9.7717^{\mathrm{ns}}$ & $0.7450^{* *}$ & $2408.9709^{* *}$ & $0.6734^{*}$ & $2.4207^{*}$ & $52.5446^{*}$ \\
\hline Mean heterosis & 1 & $16.2971^{* *}$ & $0.0476^{\mathrm{ns}}$ & $0.0525^{\mathrm{ns}}$ & $1.8122^{* *}$ & $8952.8115^{* *}$ & $2.6745^{* *}$ & $3.8477^{* *}$ & $525.5695^{* *}$ \\
\hline Varietal heterosis & 5 & $2.1634^{* *}$ & $7.6393^{* *}$ & $10.3199^{\mathrm{ns}}$ & $0.2174^{\mathrm{ns}}$ & $2171.8999 *$ & $0.7075^{*}$ & $2.4716^{\mathrm{ns}}$ & $1.8965^{\mathrm{ns}}$ \\
\hline Specific heterosis & 9 & $1.8832^{* *}$ & $2.5221^{*}$ & $10.5470^{\mathrm{ns}}$ & $0.9195^{* *}$ & $1813.5834^{*}$ & $0.4322^{\text {ns }}$ & $2.2338^{\mathrm{ns}}$ & $28.1241^{\mathrm{ns}}$ \\
\hline Residual & 180 & 0.4749 & 1.2676 & 8.2676 & 0.1599 & 839.2109 & 0.3461 & 1.3427 & 38.3374 \\
\hline
\end{tabular}

${ }^{(1)} \mathrm{MNDE}=$ number of days for germination; NDF = number of days to flowering; MHFPI= mean height of the insertion of the first pod; $\mathrm{MLLP}=$ mean pod longitudinal length; $\mathrm{MFPH}=$ mean final plant height; $\mathrm{MSNP}=$ mean number of seeds per $\mathrm{pod} ; \mathrm{MSW}=$ mean weight of 50 seeds; and GY = grain yield.

**Significant at the $1 \%$ level of probability by the $\mathrm{F}$ test.

*Significant at the $5 \%$ level of probability by the $\mathrm{F}$ test.

ns no significant. 
parents differed or had favorable genetic complementation in the crosses tested.

The joint analysis of the genotype effects of cultivars and heterosis showed that: a) there was expressive genetic variability among the parents included in the diallel; $b$ ) the parents were promising in gains per $s e$; and c) the effects of genetic complementation were satisfactory for nearly all the characters assessed.

\subsection{Estimates of the cultivars effect}

Regarding the $\widehat{V}_{i}$ estimates, VencovsKy (1970) and CRUZ AND REgAZZI (1994) pointed out that cultivars with positive effect contribute to increase the value of the traits in their hybrids, while those with negative effect contribute to reduce the magnitude.

Based on this assumption, LPSPI 93-17 and FT Nobre cultivars have the greatest potential per se for inclusion in hybrid programs for the MNDE trait, increasing the seed vigor and resulting in more rapid emergence of seedlings. The Campeão-1 and Rudá cultivars, in this order, would tend to contribute undesirably to plant vigor because they have the greatest positive values for $\hat{V}_{\mathrm{i}}$.

Still referring to MNDE, LPSPI 93-19 cultivar had positive small value for $\widehat{V}_{i}(0.0166)$. Therefore, 'LPSPI 93-19' should not be disregarded when the breeding strategy is for cultivars with greater seed vigor.

The joint analysis of traits MNDE and NDF indicate that LPSPI 93-19 and FT Nobre cultivars should be given more attention in the Northwest Region of Paraná State in future breeding programs for cultivars with reduced emergence and flowering periods. This possibility would result in early cultivars, allowing farmers to better use the cropped area with a greater number of harvests during the year; consequently the purchasing power of the rural population would increase with the offer of an out of season product (BARELLI, 1997).

LPSPI 93-17, LPSPI 93-19 and Aporé cultivars had positive $\hat{v}_{i}$ values for height of insertion of the first pod (MHFPI), which is in line with results obtained by BARELLI (1997) based on the $\hat{\mathrm{g}}_{\mathrm{i}}$ values, using Griffing's dialell analysis (1956). This proves that such cultivars should be used to increase this trait in breeding programs. This is of great importance in crops where mechanized harvesting is used, as a way of avoiding contact of pods with the soil and consequent degradation of the product to be harvested.

LPSPI 93-19 and Aporé cultivars had the greatest positive $\hat{\vartheta}_{i}$ values for MLLP. These cultivars should therefore be preferred in selection per se or for use in crosses for increased pod size.

LPSPI 93-17 and Rudá cultivars had positive $\hat{\mathrm{v}}_{\mathrm{i}}$ values for the MFPH trait, while 'LPSPI 93-19', 'FT Nobre', 'Aporé' and 'Campeão-1' had negative values. Although Rudá cultivar had an indeterminate and prostrate growth habit, it is classified between groups II and III, which may have contributed to the manifestation of a lower positive $\hat{\vartheta}_{i}$ value for MFPH (Table 3).

LPSPI 93-17, FT Nobre, Rudá and Campeão-1 cultivars had positive $\hat{\mathrm{V}}_{\mathrm{i}}$ values for MSNP. These cultivars are of interest when an increase in the number of seeds per pod is required. Consequently a reduction in grain weight is expected from plants originating in these programs, which is confirmed by the negative values for MSW in all cultivars, except 'Campeão-1' (Table 3).

Table 3. Estimates of the mean parameters, the cultivars effect $\left(\widehat{\vartheta}_{i}\right)$ and their standard error (SE) for eight agronomic traits assessed in six common bean cultivars, and their $F_{1}$ 's hybrids, according to Gardner and Ebeharts' method (1966)

\begin{tabular}{|c|c|c|c|c|c|c|c|c|}
\hline \multirow[t]{2}{*}{$\hat{V}_{\mathrm{i}}($ Cultivar) } & \multicolumn{8}{|c|}{ Characterstics ${ }^{(1)}$} \\
\hline & MNDE & NDF & MHFPI & MLLP & MFPH & MSNP & MSW & GY \\
\hline 1. LPSPI 93-17 & -0.7833 & 2.1666 & 1.0041 & -0.2808 & 18.8000 & 0.4751 & -0.0271 & -2.3523 \\
\hline 2. LPSPI 93-19 & 0.0166 & -1.5333 & 3.5166 & 0.3631 & -15.3999 & -0.5978 & 1.2520 & -3.0105 \\
\hline 3. FT Nobre & -0.7833 & -0.5333 & -1.0833 & -0.7588 & -1.6000 & 0.1021 & -1.8636 & -1.1901 \\
\hline 4. Aporé & 0.2166 & -1.7333 & 1.0541 & 0.7991 & -3.8999 & -0.2608 & 1.3280 & 2.6544 \\
\hline 5. Rudá & 0.8166 & 0.7666 & -2.1208 & -0.1078 & 3.3000 & 0.1091 & -1.0054 & 2.7089 \\
\hline 6. Campeão-1 & 0.5166 & 0.8666 & -2.4458 & -0.0148 & -1.1999 & 0.1721 & 0.3160 & 1.1906 \\
\hline Cultivars mean & 5.4833 & 41.0333 & 17.9833 & 12.0648 & 143.5000 & 5.2138 & 13.7545 & 32.0781 \\
\hline SE (Cultivars mean) & 0.0888 & 0.1452 & 0.1982 & 0.0509 & 3.7398 & 0.0075 & 0.0793 & 0.4272 \\
\hline $\mathrm{SE}\left(\mathrm{V}_{\mathrm{i}}\right)$ & 0.1987 & 0.2297 & 0.5868 & 0.1153 & 8.3626 & 0.1698 & 0.2364 & 1.2638 \\
\hline $\mathrm{SE}\left(\mathrm{V}_{\mathrm{i}}-\mathrm{V}_{\mathrm{j}}\right)$ & 0.3080 & 0.3559 & 0.9092 & 0.1786 & 12.9553 & 0.2630 & 0.3663 & 1.9579 \\
\hline
\end{tabular}

${ }^{(1)} \mathrm{MNDE}$ = number of days for germination; NDF = number of days to flowering; MHFPI= mean height of the insertion of the first pod; $\mathrm{MLLP}=$ mean pod longitudinal length; $\mathrm{MFPH}=$ mean final plant height; $\mathrm{MSNP}=$ mean number of seeds per pod; $\mathrm{MSW}=$ mean weight of 50 seeds; and GY = grain yield. 
Aporé, Rudá and Campeão-1 cultivars had positive $\hat{V}_{i}$ values for grain yield (GY). Therefore when breeding for superior mean yields (grams per plant), these cultivars would be desirable to supply gains per se or in intercrossing.

According to SINGH AND CHAUdARY (1985) the range of variation among the parents and between two parents differ when their amplitude is greater than twice the respective standard error. Table 3 shows the presence of variability among the parents for all the traits with greater and smaller $\hat{\vartheta}_{\mathrm{i}}$ effects: $\operatorname{MNDE}$ (5.19), NDF (10.95), MHFPI(6.55), MLLP (8.72), MFPH (2.63), MSNP (4.07), MSW (8.71) and GY (2.58).

\subsection{Estimates of mean varietal and specific heterosis}

There was a discrepancy among the sign of $\hat{\nabla}_{i}$ (Table 3) and $\hat{h}_{i}$ (Table 4) for the traits MNDE, NDF, MLLP, MFPH and MSNP, which is the result of using very divergent cultivars (VENCOVSKY, 1970; CRUZ AND RegazZI, 1994; Amaral JúNIOR, 1996). Thus, selection

Table 4. Estimates of the effects of mean $(\overline{\mathrm{h}})$, varietal $\left(\hat{\mathrm{h}}_{\mathrm{i}}\right)$ and specific $\left(\hat{\mathrm{s}}_{\mathrm{ij}}\right)$ heterosis and its standard error (SE) for eight traits assessed in six common bean cultivars, according to Gardner and Ebehart's method (1966)

\begin{tabular}{|c|c|c|c|c|c|c|c|c|}
\hline \multirow[t]{2}{*}{ Effects } & \multicolumn{8}{|c|}{ Characteristics $^{(1)}$} \\
\hline & MNDE & NDF & MHFPI & MLLP & MFPH & MSNP & MSW & GY \\
\hline Mean heterosis $(\overline{\mathrm{h}})$ & 0.6166 & - & - & 0.2056 & 14.4553 & 0.2498 & 0.2996 & 3.5018 \\
\hline $\mathrm{SE}(\overline{\mathrm{h}})$ & 0.1048 & - & - & 0.0608 & 4.4250 & 0.0894 & 0.1760 & 0.9457 \\
\hline \multicolumn{9}{|l|}{ Varietal heterosis $\left(\widehat{\nabla}_{\mathrm{i}}\right)$} \\
\hline 1. LPSPI 93-17 & 0.2416 & -1.0666 & - & 0.0330 & -3.3666 & -0.3361 & - & - \\
\hline 2. LPSPI 93-19 & -0.3083 & -0.1916 & - & -0.0949 & 0.8583 & 0.1028 & - & - \\
\hline 3. FT Nobre & -0.4083 & -0.1166 & - & -0.0931 & -8.3666 & 0.0435 & - & - \\
\hline 4. Aporé & 0.0416 & 0.3333 & - & 0.1343 & 20.3833 & 0.2130 & - & - \\
\hline 5. Rudá & -0.0333 & 0.3333 & - & -0.0824 & -4.4166 & 0.0415 & - & - \\
\hline 6. Campeão-1 & 0.4666 & 0.7083 & - & 0.1030 & -5.0916 & -0.649 & - & - \\
\hline $\mathrm{SE}\left(\hat{\mathrm{h}}_{\mathrm{i}}\right)$ & 0.1403 & 0.2297 & - & 0.0812 & 5.132 & 0.1200 & - & - \\
\hline$S E\left(h_{i}-h_{j}\right)$ & 0.2177 & 0.3559 & - & 0.1260 & 9.1608 & 0.1860 & - & - \\
\hline \multicolumn{9}{|l|}{ Specific heterosis $\left(\hat{\mathrm{s}}_{\mathrm{ij}}\right)$} \\
\hline $1 \times 2$ & 0.3499 & - & - & -0.3087 & -0.0449 & - & - & - \\
\hline $1 \times 3$ & -0.7500 & - & - & 0.1714 & -6.6199 & - & - & - \\
\hline $1 \times 4$ & 0.1999 & - & - & 0.1969 & 5.4799 & - & - & - \\
\hline $1 \times 5$ & 0.1749 & - & - & -0.0438 & 5.2800 & - & - & - \\
\hline $1 \times 6$ & 0.0249 & - & - & -0.0158 & -4.0950 & - & - & - \\
\hline $2 \times 3$ & -0.4000 & - & - & 0.4884 & -14.4449 & - & - & - \\
\hline $2 \times 4$ & 0.1499 & - & - & -0.1690 & 19.2550 & - & - & - \\
\hline $2 \times 5$ & -0.0750 & - & - & -0.2337 & -10.2449 & - & - & - \\
\hline $2 \times 6$ & -0.0250 & - & - & 0.2231 & 5.4799 & - & - & - \\
\hline $3 \times 4$ & 0.1499 & - & - & -0.3288 & 5.9800 & - & - & - \\
\hline $3 \times 5$ & 0.5249 & - & - & -0.1165 & 13.4799 & - & - & - \\
\hline $3 \times 6$ & 0.4749 & - & - & -0.2145 & 1.6050 & - & - & - \\
\hline $4 \times 5$ & -0.3249 & - & - & 0.3439 & -18.1199 & - & - & - \\
\hline $4 \times 6$ & -0.1750 & - & - & -0.0430 & -12.5949 & - & - & - \\
\hline $5 \times 6$ & -0.3000 & - & - & 0.0501 & 9.6050 & - & - & - \\
\hline $\mathrm{SE}\left(\hat{\mathrm{S}}_{\mathrm{ij}}\right)$ & 0.1685 & - & - & 0.0974 & 7.0959 & - & - & - \\
\hline $\mathrm{SE}\left(\hat{\mathrm{s}}_{\mathrm{ij}}-\mathrm{S}_{\mathrm{ik}}\right)$ & 0.2668 & - & - & 0.1545 & 11.2196 & - & - & - \\
\hline $\operatorname{SE}\left(\hat{S}_{\mathrm{ij}}-\mathrm{Skl}_{\mathrm{kl}}\right)$ & 0.2177 & - & - & 0.1260 & 9.9210 & - & - & - \\
\hline
\end{tabular}

${ }^{(1)} \mathrm{MNDE}=$ number of days for germination; $\mathrm{NDF}=$ number of days to flowering; $\mathrm{MHFPI}=$ mean height of the insertion of the first pod; $\mathrm{MLLP}=$ mean pod longitudinal length; $\mathrm{MFPH}=$ mean final plant height; $\mathrm{MSNP}=$ mean number of seeds per pod; $\mathrm{MSW}=\mathrm{mean}$ weight of 50 seeds; and GY = grain yield. 
for these traits should be based on the estimates of the effects of the cultivars $\left(\widehat{\vartheta}_{\mathrm{i}}\right)$ (CRUZ AND REGAZZI, 1994).

Based on this premise, increases in seed vigor could be reached using LPSPI 93-17 and FT Nobre cultivars crossed with 'Rudá' and 'Campeão- 1 ' as in Table 3. Similarly earlier genotypes could be obtained in programs of intercrossings involving cultivars LPSPI 93-17, LPSPI 93-19, Aporé and Campeão-1. The indicated cultivars for gain in pod longitudinal length are LPSPI 93-17, LPSPI 93-19, FT Nobre and Aporé, while LPSPI 93-19, FT Nobre, Aporé and Campeão-1 could contribute to obtain shorter genotypes. Nevertheless, when taller cultivars are required LPSPI 93-19 and Rudá cultivars are the most viable options. The best options for selection gains in number of seeds per pod are 'LPSPI 93-17', 'LPSPI 93-19', 'FT Nobre' and 'Rudá'.

The estimates of the specific heterosis effect for MNDE show favorable effects for increase in seed vigor from the crosses $1 \times 3,2 \times 3,2 \times 5,2 \times 6,4 \times 5,4$ $\times 6$ and $5 \times 6$, because they have negative $\hat{s}_{\mathrm{ij}}$ values (Table 4). The performance of hybrids 1 (LPSPI 93-17) x 3 (FT Nobre) and 2 (LPSPI 93-19) x 3 (FT Nobre) should be emphasized because they have greater negative values, -0.7500 and -0.4000 , respectively.

Regarding the MLLP trait, crosses $1 \times 3,1 \times 4,2 \times$ $3,2 \times 6,4 \times 5$, and $5 \times 6$ could be indicated for programs for plants with more accentuated pod longitudinal length because they have positive $\hat{s}_{\mathrm{ij}}$ values (Table 4).

MFPH trait had seven combinations with negative $\mathrm{s}_{\mathrm{ij}}$ values: $1 \times 2,1 \times 3,1 \times 6,2 \times 3,2 \times 5,4 \times 5$, and $4 \times 6$. They should be preferred when shorter plants are required. On the other hand, if the aim is obtaining taller plants, crosses $2 \times 4,3 \times 5$, and $5 \times 6$ with greatest positive $\hat{s}_{\mathrm{ij}}$ values $(19.2550,13.4799$ and 9.6050$)$ respectively (Table 4), should be preferred.

Based on the set of traits assessed, the greatest potentials for reducing the emergence and flowering periods were expressed in 'LPSPI 93-17' x 'FT Nobre' and 'LPSPI 93-19' x 'FT Nobre'. Satisfactory gains could be reached when cultivars LPSPI 93-17, Aporé, Rudá and Campeão-1 are the parents to be intercrossed for number of seeds per pod and grain yield.

\section{CONCLUSIONS}

1. There was sufficient genetic variability among the parents involved in the diallel. The effects of genetic complementation were satisfactory for all the assessed traits, except for MHFPI.

2 . The greatest potential for reduction in the emergence and flowering periods was expressed in LPSPI 93-17 x FT Nobre and LPSPI 93-19 x FT Nobre hybrids. Cultivars LPSPI 93-17, Aporé, Rudá and Campeão-1 have the greatest potential per se or for intercrossing for number of seeds per pod and grain yield.

\section{REFERENCES}

AMARAL JÚNIOR, A.T. Análise dialélica de betacaroteno, vitamina $C$, sólidos solúveis e produção e variabilidade em cultivares de tomateiro (Lycopersicon esculentum) via marcadores RAPD. Viçosa, 1996. 198p. Tese (Doutorado em Genética e Melhoramento) - UFV.

BARELLI, M.A.A. Análise dialélica da capacidade combinatória de cultivares de feijão (Phaseolus vulgaris L.) adaptadas ao Nororeste Paranaense. Maringá, 1997. 64p. Tese (Mestrado em Melhoramento Genético Vegetal) - Universidade Estadual de Maringá.

CRUZ, C.D.; REGAZZI, A.J. Modelos biométricos aplicados ao melhoramento genético. Viçosa, Imprensa Universitária, 1994. 394p.

DEMARCHI, M. Grãos: feijão. Acompanhamento da situação agropecuária no Paraná, Curitiba, v.21, n.9, p.22-39, 1995.

DEMARCHI, M. Grãos: feijão. Acompanhamento da situação agropecuária no Paraná, Curitiba, v.23, n.9, p.17-24, 1997.

GARDNER, C.O.; EBEHART, S.A. Analysis and interpretation of the variety cross diallel and related populations. Biometrics, London, v.22, p.439-452, 1966.

GRIFFING, B. Concept of general and specific combining ability in relation to diallel crossing systems. Australian Journal of Biologycal Sciences, Melbourne, v.9, p.462-493, 1956.

PAINI, J.N. Capacidade combinatória e heterose em oito variedades de milho (Zea mays L.) avaliadas sob condições climáticas da Região Sul do Brasil. Viçosa, 1994. 125p. Tese (Mestrado em Genética e Melhoramento) - UFV.

SINGH, R.K.; CHAUDARY, B.D. Biometrical methods in quantitative genetic analysis. New Delhi: Kalyani, 1985. $318 \mathrm{p}$.

SINGH, M.; SINGH, R.K. A comparison of different methods of half-diallel analysis. Theoretical and Applied Genetics, Berlin, v.67, p.623-626, 1984.

SOUZA JÚNIOR, C.L. Análise de cruzamentos dialélicos e predição de compostos de milho (Zea mays L.) braquítico. Piracicaba, 1981. 102p. Tese (Doutorado em Genética e Melhoramento de Plantas) - ESALQ/USP.

VENCOVSKY, R. Alguns aspectos teóricos e aplicados relativos a cruzamentos dialélicos de variedades. Piracicaba, 1970. 59p. Tese (Livre Docência) - ESALQ/USP.

VIEIRA, C. Cultura do feijoeiro. In: ZIMMERMANN, M.J.O.; ROCHA, M.; YAMADA, T. Perspectivas da cultura do feijão e de outras leguminosas de grão no país e no mundo. Piracicaba: Potafos, 1988. p.3-20. 